\title{
ARTIKELEN
}

\section{Securitisering en seksualisering van migratie: het debat over oud en nieuw in Keulen}

\author{
Martina Althoff
}

\section{Inleiding}

De aanrandingen en berovingen tijdens oudejaarsnacht 2015 in Keulen hebben nationaal en internationaal veel aandacht getrokken. Door een wekenlang aanhoudend publiek debat is Keulen een mediagebeurtenis geworden waarop burgers en instanties geschokt hebben gereageerd. De verhalen en beschrijvingen van die nacht leidden al gauw tot het aanwijzen van oorzaken en het toewijzen van schuld. Een kenmerk van die nacht is echter dat er onduidelijkheid blijft bestaan over wat er precies is gebeurd. Het publieke debat hierover is dan ook te begrijpen als een poging tot zingeving.

Gebeurtenissen hebben zelf geen betekenis, maar krijgen betekenis door middel van de culturele framing die in en door het publieke debat plaatsvindt. Publieke discoursen zijn vormen van maatschappelijke communicatie waarin de sociale werkelijkheid wordt geconstrueerd. Dat betekent dat de zogenoemde realiteit pas werkelijk wordt door betekenissen. Een hiermee verbonden veronderstelling is dat er nergens 'pure of eenvoudige feiten' bestaan, maar dat altijd sprake is van geïnterpreteerde 'feiten'. Spreken over de werkelijkheid maakt tegelijkertijd deel uit van die werkelijkheid (cf. Schütz, 1971).

Interpretaties en betekenissen staan niet los van de maatschappij en zijn in die zin niet willekeurig, maar sluiten aan bij cultureel beschikbare betekenissen. Ze maken gelijktijdig deel uit van de betekenisproductie in de maatschappij. Betekenisverlening moet volgens dit perspectief in relatie tot de maatschappelijke context worden beschouwd. De maatschappelijke communicatie wordt niet alleen direct, maar ook indirect, op de achtergrond, door maatschappelijk veranderde interpretaties beïnvloed. Stilzwijgend wordt aangesloten bij de denkbeelden, niet alleen om begrijpelijk en overtuigend te zijn, maar ook om begrip en instemming te ontvangen (Althoff, 2010: 204).

De socioloog Erving Goffman (1974) noemt dit het primary framework: routineuze verwachtings- en interpretatiepatronen, waarbij aan bepaalde situaties specifieke betekenissen worden toegeschreven die mensen helpen deze gebeurtenissen te begrijpen.

'When the individual in our Western society recognizes a particular event, he tends, whatever else he does, to imply in this response (and in effect employ) one or more frameworks or schemata of interpretation of a kind that can be called primary' (Goffman, 1974: 21). 
In de visie van Goffman kunnen in alle situaties verschillende frames als geroutiniseerde definities van de situatie naast elkaar bestaan:

'Taken all together, the primary frameworks of a particular social group constitute a central element of its culture, especially insofar as understandings emerge concerning principal classes of schemata, the relation of these classes to one another, and the sum total of forces and agents' (ibid., 1974: 27).

De verschillende media zijn de belangrijkste instanties die over de gebeurtenis berichten, maar ook de belangrijkste wat het aanleveren van betekenissen betreft. In het publieke debat mengen zich ook andere actoren, die deels via de media en deels via eigen debatten of (internet)platformen de gebeurtenis bespreken en er betekenissen aan toekennen. Er vindt een definitiestrijd plaats over hoe de gebeurtenis - de oudejaarsnacht van Keulen - te interpreteren valt. Voorbeelden zijn politici of parlementsleden die de betekenis en de consequenties van de gebeurtenis voor bijvoorbeeld wetgeving en beleid bediscussiëren. De verschillende publieke discussies en debatten bij elkaar vormen het maatschappelijk discours over oud en nieuw in Keulen. Door dit publieke discours krijgt de gebeurtenis een specifieke interpretatie en wordt de betekenis geconstrueerd.

Twee aspecten zijn hier belangrijk: sociale betekenissen worden dus in publieke discoursen geproduceerd en taal is niet slechts een medium, maar tegelijk een vorm van handelen die de wereld mede construeert (Althoff, 2010: 203; Prins, 2000: 16). Een analyse van het discours over de oudejaarsnacht in Keulen heeft vanuit dit perspectief twee doelen: ze geeft zicht op de gebeurtenis, de verschillende frames en de hiermee verbonden betekenisgeving. Ze geeft antwoord op de vraag - in Goffmans woorden - wat hier eigenlijk aan de hand is. Framing schept dus orde door de situatie, het probleem te definiëren, oorzaken en verantwoordelijkheden toe te schrijven, morele oordelen te vellen en specifieke probleemoplossingen voor te stellen. Daarnaast laat een framinganalyse zien welke waarnemingen en interpretaties van de gebeurtenissen dominant zijn geworden, dit omdat collectief geaccepteerde betekenissen in publieke discoursen verankerd zijn. Framinganalyse kan dus geïnstitutionaliseerde betekenissen reconstrueren. Aan de resultaten van een dergelijke analyse kunnen uiteindelijk weer betekenissen worden toegeschreven door bijvoorbeeld sociale wetenschappers. Volgens Schütz (1971) is hier sprake van 'constructies van constructies' of van constructies van de tweede graad of tweede orde. Voor de analyse van de oudejaarsnacht in Keulen rijst dus de vraag hoe de gebeurtenis beschreven en verklaard wordt, hoe zij benoemd en geïnterpreteerd wordt, welke betekenis zij collectief toegewezen krijgt en hoe deze inzichten theoretisch te duiden zijn.

De volgende analyse laat zien dat er verschillende frames mogelijk waren. De aanrandingen die nacht hadden kunnen leiden tot een discours over seksueel geweld in de publieke ruimte, een frame dat bijvoorbeeld seksuele discriminatie en intimidatie van vrouwen en de genderrelaties als focus heeft. Een ander frame had de problematisering van het werk van de politie tijdens de oudejaarsnacht kunnen zijn, dat een specifieke partij verantwoordelijk stelt. In plaats hiervan richtte het discours zich op het (seksuele) gedrag van vluchtelingen en hun ideeën over gen- 
derrelaties. Aan de hand van een framinganalyse kan worden onderzocht welke betekenis oud en nieuw in Keulen als mediale gebeurtenis voor de maatschappij heeft.

De onderstaande analyse kent vier stappen: allereerst wordt de gebeurtenis gereconstrueerd en wordt een uitgebreide casusanalyse gemaakt. De reconstructie is gebaseerd op met name materiaal dat door de overheid en politie publiek beschikbaar is gesteld. ${ }^{1}$ In het hiervoor geschetste theoretisch perspectief is een dergelijke casusbeschrijving op basis van het getypeerde materiaal geen neutrale beschrijving van het gebeuren, maar een (re)constructie van de tweede orde. In de tweede stap worden het publieke debat en de verschillende frames en verklaringen van de gebeurtenissen beschreven en geanalyseerd. Een reconstructie van de mediaberichtgeving over de nacht in Keulen vindt plaats op basis van bestaande media-analyses; daarnaast wordt het maatschappelijke debat gereconstrueerd, waaronder het protest vanuit het politiek-feministische tijdschrift EMMA en de feministische beweging Ausnahmslos. Daarna wordt onderzocht wat de effecten van de verschillende frames zijn voor de politieke discussie over beleid en wetgeving. Ten slotte volgt een theoretische discussie waarin de maatschappelijke betekenis van het discours over Keulen wordt besproken. Samenvattend is de centrale vraag hoe interpretatieve frames de reconstructie van een gebeurtenis bepalen die op veel maatschappelijke, culturele en politieke niveaus impact heeft.

\section{Oud en nieuw 2015 in Keulen: een casusanalyse}

De wereldberoemde kathedraal van Keulen, de Kölner Dom, heeft een bijzondere ligging. Hij staat majestueus aan de Rijnoever en komt meteen in beeld als je met de trein over de Rijnbrug rijdt, voordat de trein in het centraal station verdwijnt. Een grote brede trap leidt van het kleine plein bij het centraal station naar boven tot aan de kathedraal, waar een enorm groot plein de kathedraal met de binnenstad verbindt. Dit plein, de Domplatte genaamd, is een populaire plek voor straatevenementen en is ideaal om af te spreken, ook als je de stad nog niet kent.

Tijdens de oudejaarsnacht van 2015 verzamelen zich volgens de politie en passanten opvallend veel jonge mannen met een allochtoon uiterlijk voor het station. Ze doen daar spelletjes, stoeien met elkaar en gooien vuurwerk naar elkaar. Dit gaat gepaard met alcohol- en drugsconsumptie. Rond tien uur die avond is hun aantal gegroeid tot duizend mensen. Vanwege de drukte die is ontstaan op de trap tussen de Domplatte en het station besluit de politie rond dit tijdstip haar krachten op deze plek te bundelen. De vrees is dat er paniek uitbreekt, maar ook dat de

1 Medio 2016 heeft de politie in Noordrijn-Westfalen (NRW) de balans opgemaakt en het ministerie van Binnenlandse Zaken van NRW heeft persberichten en Einsatzunterlagen op internet publiek beschikbaar gemaakt. Ook het verslag van een parlementaire onderzoekscommissie van het deelstaatparlement in NRW, de zogenoemde PUA (Parlamentarischer Untersuchungsausschuss), over Silvesternacht 2015 wordt openbaar toegankelijk gemaakt. Een hierop gebaseerd samenvattende beschrijving en analyse worden geleverd door (voormalig politieman) Behrendes (2016: 323-327), een chronologische tabel van die nacht, opgesteld door criminoloog en politieonderzoeker Pütter (2016: 49). 
drukte tot valpartijen zou kunnen leiden. Daarom wordt besloten de trap (en uiteindelijk ook het plein voor het station) te laten ontruimen, waarbij wordt geprobeerd corridors naar de in- en uitgangen van het station vrij te houden. Dit duurt tot half twaalf. De groepen jonge mannen begeleiden de activiteiten van de politie met verbale agressie. Ook in het centraal station zelf is het erg druk en hebben zich groepen jonge mannen verzameld. Doordat de politie in verband met de ontruiming tijdelijk niet alleen de in- en uitgangen van het station, maar ook de toegang tot de perrons sluit, ontstaat hier extreme drukte. Getuigen spreken zelfs van chaotische toestanden (Behrendes, 2016). De sluiting van het station heeft ook effect op de reeds bestaande drukte op de Rijnbrug, van waaraf traditioneel veel mensen het vuurwerk bekijken (PUA, 2017). Na het vuurwerk wordt het langzaam rustiger en vertrekken er veel mensen, onder andere naar de horeca.

\section{Daders en verdachten, aangiftes en slachtoffers}

Terwijl de politie haar maatregelen uitvoert, komen bij enkele politieagenten berichten binnen over diefstal van mobieltjes en portemonnees en over aanrandingen. De politie adviseert de betrokkenen aangifte te doen op het politiebureau in de buurt. Pas na middernacht krijgt de politie meer zicht op het totale plaatje; de politiemensen bij de verschillende afzettingen worden op de hoogte gebracht van de diefstallen en aanrandingen die in de drukte worden gepleegd. Vrouwen berichten dat ze spitsroeden moesten lopen tussen groepen agressieve jonge mannen, waarbij hun mannelijke begeleiders in de drukte met geweld van hen werden gescheiden. Naar latere schatting hebben vrouwen die nog diezelfde nacht aangifte wilden doen daarvan afgezien vanwege de drukte op het politiebureau en de wachtrij. Uiteindelijk hebben op nieuwjaarsochtend vier vrouwen aangifte gedaan van diefstal en aanranding. In het begin van de middag is er elf keer aangifte gedaan en in de loop van de dag nemen de aantallen verder toe. Het commissariaat van de politie stelt diezelfde dag nog een speciaal rechercheteam samen. Op 2 januari roept de politie alle slachtoffers publiekelijk op aangifte te doen. Op 5 januari zijn er honderd aangiftes gedaan en op 10 januari is er sprake van negentien verdachten (PUA, 2016: 2). De publieke aandacht neemt toe en de overheid roept iedereen herhaaldelijk op om aangifte te doen. Begin september 2016 zijn er 1201 aangiftes gedaan tegen 1600 delicten, waarvan 505 tegen aanranding. Hiervan zijn 27 processen-verbaal voor (poging tot) verkrachting (hier: door met vingers met geweld in de vagina binnen te dringen). De aangiftes inzake aanranding omvatten met name het aanraken van borsten en schaamdelen boven de kleding. De delicten worden rond middernacht gepleegd, op het moment van de grootste drukte in het centraal station en op de Domplatte (Behrendes, 2016: 327; Pütter, 2016: 47).

De modus operandi van de daders wordt door de onderzoeksgroep onder leiding van het Bundeskriminalamt als volgt beschreven:

'Die Täter umringen ihre Opfer, trennen sie von männlichen Begleitern und belästigen sie sexuell. Der Umfang dieses sexuellen Missbrauchs reicht von ungebetenen sexuellen Angeboten und verbalen Belästigungen über physische Übergriffe wie aufgezwungenen Küssen, Umklammern, Anfassen des 
Genital- oder Brustbereichs oberhalb der Kleidung bis hin zu gemeinschaftlich begangenen Vergewaltigungen. Die Opfer werden bei der Tatbegehung teilweise zeitgleich bestohlen bzw. beraubt.' (Behrendes, 2016: 328)

Volgens de beschrijving van de later ingerichte parlementaire onderzoekscommissie (PUA, 2016) ${ }^{2}$ hebben zich op een bepaald tijdstip op het beschreven terrein meer dan duizend mensen verzameld, waarvan de meerderheid mannen tussen de 15 en 35 jaar oud met een Noord-Afrikaans of Arabisch aandoend uiterlijk. De opsporing is gericht op 286 verdachten. Tot begin september 2016 is van 152 van hen de identiteit vastgesteld: 79 asielzoekers, 12 gedoogde personen, 39 illegalen, 22 Duitsers. Meer dan 150 van de 286 verdachte personen komen uit Algerije en Marokko, 60 uit Syrië of Irak. Het Openbaar Ministerie (OM) heeft 31 aanklachten ingediend (Pütter, 2016: 47). ${ }^{3}$

Een uitgebreide dossieranalyse door $\mathrm{Egg}^{4}$ van alle beschikbare aangiftes van die nacht levert het volgende beeld op: er zijn 1022 delicten gepleegd waarvan 29,6\% uitsluitend zedendelicten, $17,2 \%$ een combinatie van zeden- en vermogensdelicten, en $46,5 \%$ van de aangiftes heeft alleen betrekking op vermogensdelicten. In totaal houdt bijna de helft $(46,8 \%)$ van alle aangiftes verband met aanranding en andere zedendelicten. Driekwart $(76,8 \%)$ van de meer dan duizend slachtoffers was vrouw, waarbij $42,7 \%$ van hen uitsluitend melding maakt van seksuele delicten. $21,9 \%$ van de vrouwelijke slachtoffers doet aangifte van een combinatie van seksuele en vermogensdelicten. Opvallend is volgens Egg dat de categorisering door de politie ten eerste ongelijkmatig is en vervolgens grotendeels onbegrijpelijk. Zo worden vergelijkbare delictsomschrijvingen door de slachtoffers strafrechtelijk zeer verschillend geïnterpreteerd. Vervolgens blijkt de strafrechtelijke categorisering door de politie, met dat de publieke aandacht voor de gebeurtenis in Keulen toeneemt, vanaf 4 januari duidelijk te verschuiven in de richting van een zwaardere delictsomschrijving. Bovendien worden reeds toegepaste categoriseringen gecorrigeerd. Er vindt dus deels een hercategorisering van de reeds opgenomen aangiftes plaats. Getypte aangiftes worden volgens dit rapport achteraf handmatig gecorrigeerd.

\section{Politiewerk}

Volgens Behrendes (2016: 324-25) hoort de speciale politie-inzet op de bekende plekken rondom de grote kathedraal, de Domplatte, de Rijnoever en de Rijnbrug-

2 Landtag Nordrhein-Westfalen, 16. Wahlperiode, Drucksache 16/10798, www.landtag.nrw.de/ portal/WWW/GB_I/I.1/PUA/PUA_IV_16._WP/MMD16-10798_Einsetzungsantrag.pdf (geraadpleegd 13-02-2017).

3 Landelijk is er in de oudejaarsnacht sprake van 2000 mannelijke daders en 1200 vrouwelijke slachtoffers in verschillende Duitse steden, www.sueddeutsche.de/politik/uebergriffe-in-koelnfrauen-wurden-opfer-von-silvester-gewalt-1.3072064 (geraadpleegd 13-2-2017).

4 De rechtspsycholoog Rudolf Egg wordt in opdracht van de parlementaire onderzoekscommissie als deskundigengetuige ingezet voor de analyse van alle aangiftes. Het rapport wordt 30 september 2016 aan de parlementaire onderzoekscommissie voorgelegd en vervolgens mondeling toegelicht en verschijnt ook als bijlage in het eindrapport. Het eindrapport is eind maart 2017 gepubliceerd, omvat 1352 bladzijden (cf. PUA, 2017). 
gen bij de standaardplanning die de politie elk jaar ter voorbereiding van de oudejaarsnacht in Keulen maakt. Op de drukste plekken dienen de agenten in uniform zichtbaar aanwezig te zijn. Op deze manier moet een probleem van de afgelopen jaren worden voorkomen, namelijk dat er vuurwerk in groepen mensen wordt gegooid. In de bewuste oudejaarsnacht vraagt het verantwoordelijke politiebureau om extra mankracht van de parate politie-eenheid, omdat de ingezette politie veel langer rond de Rijnoever en bruggen bezig is dan gepland. Uiteindelijk krijgt het bureau steun van 140 politieagenten, 50 meer dan in de oudejaarsnachten in eerdere jaren.

In de ondervraging door het PUA geeft de leider van de politieactie aan dat zij een andere inschatting had gemaakt van de gebeurtennissen. De politie was in eerste instantie bezorgd over het gooien van vuurwerk en zag dat mensen angstig probeerden weg te lopen. De politie wilde voorkomen dat het tot valpartijen op de buitentrap zou komen en er massale paniek zou ontstaan met alle gevolgen van dien, zoals tijdens de Love Parade in Duisburg in 2010, waar in het gedrang doden vielen. Hoofddoel van de politie in de oudejaarsnacht was om de agressieve groepen terug te dringen en om de buitentrap en de in- en uitgangen van het station te ontruimen. Het opbouwen van corridors tussen het station en de kathedraal en de bewaking hiervan vallen hieronder. Opvallende overlastgevers worden staande gehouden. Ongeveer zeventig mannelijke verdachten moeten zich identificeren en hun persoonlijke gegevens opgeven, er worden tien gebiedsverboden uitgesproken, en aan vijftien betrokkenen worden vrijheidsbeperkende maatregelen opgelegd.

Achteraf wordt duidelijk dat juist het politiekordon en de door de politie voorgenomen ontruiming het gedrang hebben veroorzaakt, waardoor het tot de massale aanrandingen kon komen. Het onderzoek ${ }^{5}$ naar de aangiftes van die nacht schetst hiervan een duidelijk beeld: de tijdelijke ontruiming kort voor middernacht had geen enkel preventief effect; er zijn veel meer aanwijzingen dat deze eerder averechts werkte. De aangiftes van slachtoffers maken dit achteraf duidelijk. Er blijken bovendien afstemmingsproblemen te zijn geweest tussen de verschillende politie-eenheden, waardoor de situatie in het station heeft kunnen ontstaan (Behrendes, 2016: 329). Verwijten aan de politie zijn dilettantisme, haar veiligheidsarrangement en de in die nacht genomen beslissingen (cf. Pütter, 2016: 56). Op nieuwjaarsochtend doet een medewerker van de dienstdoende persafdeling een eerste persbericht de deur uit met de titel 'Ausgelassene Stimmung - Feiern weitgehend friedlich'. Op basis van de beschikbare cijfers en informatie wordt een vergelijking gemaakt met de oudejaarsnacht van het jaar ervoor en verslag gedaan van de politie-inzet en de ontruiming. De conclusie van het persbericht is dat de situatie in de nieuwjaarsnacht over het algemeen ontspannen was, omdat de poli- 
tie op cruciale plekken zichtbaar aanwezig was. ${ }^{6}$ Een dag later publiceert dezelfde medewerker een persbericht waarin het eerste persbericht wordt aangepast en verslag wordt gedaan van de dertig aangiftes die inmiddels zijn gedaan. Hoewel er op dit moment nog geen namen bekend zijn, spreekt dit persbericht van verdachten met een Noord-Afrikaans uiterlijk. Twee dagen later, op maandag 4 januari 2016, nodigt de politiechef van Keulen de media uit voor een persgesprek. Een dag later geeft de burgermeester van de stad Keulen een persconferentie, waarin zij vertelt dat er nog geen verdachten zijn aangehouden en er derhalve nog geen informatie beschikbaar is over hun herkomst (Behrendes, 2016: 330). Bovendien adviseert de burgemeester vrouwen om tijdens het carnaval voortaan een armlengte afstand te houden van mannen.

Het persbericht leidt tot enorme kritiek aan het adres van de politie, die het verwijt krijgt dat ze hiermee de gebeurtenissen in de doofpot wil stoppen. Het persbericht wordt in de daaropvolgende dagen gecorrigeerd en aangevuld met nieuwe persberichten. De storm van kritiek op de politie-inzet blijft aanhouden. In reactie hierop treedt de politiechef van Keulen op 8 januari 2016 af 'om het vertrouwen van het publiek in de politie van Keulen te herstellen', zo luidt de officiële uitleg (Behrendes, 2016: 333). In navolging van de gebeurtenissen rondom oud en nieuw vinden verschillende demonstraties van burgers met verschillende belangen plaats, waaronder die van de anti-islambeweging Pegida, van vrouwen tegen Machogewalt en van Syrische vluchtelingen tegen geweld, racisme en seksisme. Dergelijke demonstraties vinden niet alleen in Keulen, maar ook in andere grote steden plaats.

\section{Parlementaire reactie en onderzoekscommissie}

Drie dagen later, op 11 januari, vindt een buitengewone vergadering van de vaste commissie voor Binnenlandse Zaken van het deelstaatparlement van NoordrijnWestfalen (NRW) plaats, die veel media-aandacht trekt. De politieafdeling van het ministerie voor Binnenlandse Zaken geeft hier een eerste inschatting van de gebeurtenissen in die nacht en een voorlopige beoordeling van de politie-inzet. Als cruciale fout wordt de politie verweten dat ze het aanbod van drie extra politie-eenheden, dat ze een halfuur voor middernacht kreeg, heeft afgeslagen. Dit verwijt wordt enige dagen later overgenomen door de minister-president in haar officiële excuses aan de slachtoffers voor het falen van de politie. De politie geeft als verklaring dat het mobiliseren van parate politie-eenheden uit de regio pas rond 2.00 uur's nachts tot een feitelijke versterking had kunnen leiden en daarmee te laat zou zijn gekomen (Ausschussprotokoll 11-01-2016, in: Behrendes, 2016: 335).

6 'Wie im Vorjahr verliefen die meisten Silvesterfeierlichkeiten auf den Rheinbrücken, in der Kölner Innenstadt und in Leverkusen friedlich. [...] Kurz vor Mitternacht musste der Bahnhofsvorplatz im Bereich des Treppenaufgangs zum Dom durch Uniformierte geräumt werden. Um eine Massenpanik durch Zünden von pyrotechnischer Munition bei den circa 1000 Feiernden zu verhindern, begannen die Beamten kurzfristig die Platzfläche zu räumen. Trotz der ungeplanten Feierpause gestaltete sich die Einsatzlage entspannt - auch weil die Polizei sich an neuralgischen Orten gut aufgestellt und präsent zeigte.' www.presseportal.de/blaulicht/pm/12415/3214905 (geraadpleegd 13-2-2017). 
Op 14 januari vindt een buitengewone parlementsvergadering plaats. De minister-president van de deelstaatregering van NRW spreekt van massale aanrandingen, zware criminaliteit, cruciale communicatieproblemen en foute inschattingen. De fractievoorzitter van de regerende partij (SPD) kenmerkt de oudejaarsnacht als Staatsversagen (PUA, 2016: 3). De buitengewone vergadering van de vaste commissie Binnenlandse Zaken in reactie op de gebeurtenissen in de oudejaarsnacht in Keulen leidt ertoe dat het deelstaatparlement van NRW een parlementaire onderzoekscommissie instelt: de PUA 'Silvesternacht 2015'. De commissie moet eind 2016 uitspraak doen ${ }^{7}$ over mogelijke fouten, ongeregeldheden en verzuim van onder andere de politie en andere autoriteiten, waaronder ook het ministerie van Binnenlandse en Gemeentelijke Zaken. Er wordt een uitgebreide vragenlijst met 86 vragen over de planning en de uitvoering van de politie-inzet, pers en public relations opgesteld plus een tweede vragenlijst over de algemene context. Onder de laatste vallen de personele situatie bij de politie, de ontwikkeling van geweld tegen politieambtenaren, eerdere ervaringen zoals de politie-inzet op de Love Parade, de ontwikkeling van seksueel geweld tegen vrouwen, het ontstaan van wetteloze ruimtes en de ontwikkeling van de kleine criminaliteit. Als onderzoeksperiode wordt de periode vanaf december 2010 genomen om zo ook de gebeurtenissen in eerdere oudejaarsnachten met elkaar te kunnen vergelijken. De onderzoekscommissie begint op 18 februari 2016 met haar werk en presenteert na ruim dertien maanden, meer dan zestig vergaderingen en op basis van bijna honderdtachtig getuigenverhoren haar bevindingen. ${ }^{8}$

In het slotrapport van meer dan dertienhonderd pagina's dat eind maart 2017 is gepubliceerd en vervolgens aan het deelstaatparlement van NRW is aangeboden, komt de commissie tot duidelijke conclusies over de verantwoordelijkheden. Alle betrokken overheidsinstanties hebben gefaald. De stad, de politie in Keulen en ook de federale politie hebben duidelijke fouten gemaakt bij de planning en voorbereiding van oud en nieuw en de organisatie van de politie-inzet. Vertraagde reacties, slechte communicatie en een overbelast mobilofoonnetwerk hebben het mogelijk gemaakt dat er massaal strafbare feiten werden gepleegd. Ook is er de kritiek dat bestaande overeenkomsten van eerdere jaren niet of nauwelijks zijn uitgevoerd en dat de ervaringen van oud en nieuw in 2014 onvoldoende zijn benut. Daarnaast wordt ook de communicatie door politie en politiek bekritiseerd; misleidende en foute informatie hierin hebben tot irritatie geleid. De deelstaatregering krijgt het verwijt te veel in de verdediging te schieten in plaats van mee te werken aan opheldering.

\section{De mediaberichtgeving}

Het heeft dagen geduurd voordat het publiek door de politie werd geïnformeerd over alle details van de oudejaarsnacht. Pas in de persconferenties van de politie-

$7 \quad$ Zie voetnoot 4 .

8 Diverse auteurs bekritiseren de onderzoeksopdracht aan de PUA, die eerder lijkt voor te sorteren op de aanstaande verkiezingen dan dat deze een gedetailleerd inzicht biedt in de nacht in Keulen. Zie onder andere Behrendes, 2016 en Pütter, 2016. 
chef en de burgemeester vier en vijf dagen later werden de details over de ongeregeldheden van die nacht en over de omvang van de overlast en aanrandingen naar buiten gebracht. Op social media waren voor die tijd al verhalen van slachtoffers en getuigen verschenen die vluchtelingen als daders aanwijzen (Schneider, 2016; Schorer \& Schneider, 2017). In de eerste dagen na de incidenten vindt alleen in de lokale pers een uitgebreide discussie plaats. Pas dagen daarna krijgt de gebeurtenis landelijke media-aandacht, die weken aanhoudt. Daarna volgt ook de internationale pers. Kenmerkend voor het mediadiscours is dat, naast berichten over de gebeurtenis zelf, nationaal en internationaal een stortvloed aan commentaren en discussiestukken verschijnt (Schorer \& Schneider, 2017).

De volgende analyse van de mediaberichtgeving is gebaseerd op het onderzoek van Braun-Klöppel (2016), die de Duitse berichtgeving over vluchtelingen in vier van de bekendste, als serieus beschouwde landelijke dagbladen en politieke weekbladen in die periode heeft geanalyseerd. Het betreft de Frankfurter Allgemeine Zeitung (FAZ), Süddeutsche Zeitung (SZ), Der Spiegel en FOCUS. ${ }^{9}$

\section{Dreiging door de mannelijke vluchteling}

De berichtgeving over de daders in de eerste week wordt volgens Braun-Klöppel (2016: 24) ${ }^{10}$ gekenmerkt door een discrepantie: de meerderheid van de artikelen beschrijft de daders meer algemeen als (dronken) mannen tussen 15 en 35 jaar oud, die veelal op Arabische of Noord-Afrikaanse mannen lijken. Een minderheid van de artikelen brengt religie en vluchtelingstatus expliciet in verband met de daders van de nacht van Keulen. Tegelijkertijd worden de thema's vluchtelingen en islam uitgebreid besproken in de mediaberichtgeving over de oudejaarsnacht en discursief met elkaar verbonden. Zo ontstaat een associatie met de daders.

De dreiging die van de mannelijke vluchteling uitgaat, correspondeert met hun religie, culturele gewoontes en sociaaleconomische situatie, die in de berichtgeving worden aangehaald als verklaringen voor de aanrandingen en hun genderbeeld. Voorzichtig en zonder te generaliseren naar alle moslims wordt religie verantwoordelijk gemaakt voor het gedrag van de daders (volgens BK, 33). Een typisch voorbeeld blijkt het kopje 'Unglaublich, Undenkbar, Unislamisch' (FAZ, 29-1-2016 in: BK, 34). Opvallend is dat aan de ene kant steeds wordt gesproken over de Arabische man of Arabische landen, maar dat als negatief voorbeeld Egypte wordt aangehaald. Beide dagbladen presenteren de herkomstlanden van de vluchtelingen als landen die de onderdrukking van vrouwen als kenmerk hebben en waar seksueel misbruik onderdeel van de cultuur is: 'Sind es Menschen, in deren Heimatländern sexuelle Belästigung zur Leitkultur gehört?' (FAZ, 17-1-2016, in: BK, 35). Naast religie en cultuur betreft de derde verklaringsfactor de sociaaleconomische situatie van de vluchtelingen: 'Diese Probleme sind keinem arabischen Gen geschuldet, sondern sind benennbar: Bevölkerungsexplosion und

9 De auteur heeft onder andere de berichtgeving over vluchtelingen in de eerste zes weken voor en na de oudejaarsnacht in Keulen geanalyseerd om patronen en veranderingen in het discours over vluchtelingen te ontdekken.

10 Voor de leesbaarheid van de volgende paragraaf zal Braun-Klöppel (2016) (als de hier gebruikte primaire bron) steeds in afkorting met BK worden aangeduid. 
wirtschaftliche Liberalisierung, die zu einem sichtbaren Reichtum einer weniger geführt haben, der immer grösser, obszöner wurde' (Der Spiegel, 23-1-2016, in: BK, 35). De marginalisering, zinloosheid en machteloosheid die jonge mannen in het immigratieland ervaren, leiden volgens deze argumentatie tot woede, frustratie en agressie, 'Ein Karneval der Underdogs' (Der Spiegel 16-1-2016, in: BK, 35), waarvan de nacht van Keulen de resultante lijkt te zijn. Met het oog op het aanstaande carnavalsfeest worden waarschuwingen uitgesproken en wordt de urgentie benadrukt van de culturele lessen over gendergelijkheid voor vluchtelingen, die al sinds 2015 in Duitsland worden gegeven: 'Flüchtlinge aus muslimischen Ländern werden nun, nach dem Schock der Kölner Silvester-Übergriffe, gezielt aufgeklärt, dass ein Bützchen nicht die Aufforderung zu mehr ist' (SZ, 6-2-2016, in: BK, 33). De berichtgeving maakt hier de botsing van culturen met de hierin verankerde normen en waarden verantwoordelijk voor het gedrag van de daders. Deze culturalisering van (seksueel) gedrag kenmerkt vluchtelingen en moslims dan ook als anders en de botsing als een seksuele.

\section{Dreiging door de islam}

Naast de dreiging die uitgaat van de mannelijke vluchtelingen en hun ideeën over vrouwen en genderrelaties, wordt in de mediaberichtgeving ook hun religie als dreiging beschouwd. Volgens de berichten integreren vluchtelingen uit islamitische landen moeilijker door verschillen in normen en waarden tussen de ontvangende culturen en de islamitische cultuur van herkomst. Moslims plaatsen hun religieus recht boven het recht van het immigratieland, wat tot het ontstaan van een parallelle samenleving leidt en integratieproblemen veroorzaakt. Voorbeelden die dit perspectief onderbouwen, zijn het niet aanvaarden van andere geloven, het antisemitisme en de ontkenning van het bestaansrecht van Israël (BK, 37). Praktiserende moslims worden afgeschilderd als uitdaging al dan niet als gevaar voor de Duitse en westerse cultuur. De Frankfurter Algemeine Zeitung betwijfelt de compatibiliteit van de islam en de westerse wereld: 'Der Islam hat eine Tendenz zur Gewalt. Er ist kaum anpassungsfähig an die moderne Welt' (FAZ, 5-2-2016 in: BK, 39).

In de berichtgeving is nauwelijks aandacht voor het perspectief van de vluchtelingen zelf en de risico's van hun vlucht. Er wordt wel bericht over de verontrusting en sfeer van angst onder moslims, ook in verband met het terrorisme door IS. Criminaliteit en geweld worden expliciet in verband gebracht met de islam en moslimvluchtelingen. De beschrijving van de moslim als de ander, gebaseerd op de discussie over integratieproblemen wegens hun geloof, is wat de klok slaat in de berichtgeving na Keulen (BK, 38). Meer dan de helft van de Duitsers, zo wordt gesteld, voelt zich bedreigd door de islam. Het idee van de ander impliceert een scheiding tussen 'wij en zij': de ander is moslimman of Arabisch, waartegenover 'wij' en 'onze' vrouwen staan. Het spreken over 'onze vrouwen' sluit moslima uit, maar wijst ook op een (patriarchaal) voorstel van genderrelaties, waarbij het beschermen van vrouwen door mannen dan wel door de staat als vanzelfsprekend 
en legitiem wordt beschouwd. Kwetsbaarheid en slachtofferschap komen hier samen en krijgen eenzijdig betekenis voor vrouwen. ${ }^{11}$

\section{Angst en onveiligheid}

Angst en onveiligheid zijn het dominante frame in de berichtgeving over Keulen. Niet alleen criminaliteit en geweld, de aanrandingen en diefstallen, maar ook het falen van de politie tijdens oud en nieuw en het thema migratie worden als veiligheidsprobleem geframed. Zo kopt Der Spiegel (in: BK, 43) op 16 januari met 'Staatsohnmacht. Rechtsfreie Räume, hilflose Polizei - können wir uns noch sicher fühlen?' Volgens de berichtgeving heeft het gebeurde in Keulen een angst opgewekt die blijkbaar diep verankerd is in de samenleving en het vluchtelingenbeleid betreft. Hierbij is ook de angst voor mogelijke consequenties, zoals het dichtgaan van de grenzen, een onderwerp dat wordt benadrukt: 'Ein Rückfall in die 80er-Jahre' (SZ, 22-1-2016) of 'Merkels Plan B' (FOCUS, 16-1-2016 in: BK, 45). Ook wordt er gediscussieerd over de angst dat het 'grenzen dicht'-discours wat betreft vluchtelingen en moslims de bevolking verontrust en het politiek rechtse spectrum versterkt:

'Ein Diskurs der Abgrenzung befördert die Sorgen der Bürger' en 'Die Entfremdung von "oben" und "unten" steigert sich nicht selten bis zum schieren Hass. Der rechte Rand genießt darüber immer mehr Zulauf.' (SZ, 4-2-2016; FAZ, 6-2-2016, in: BK, 41)

De angst voor meer rechtsextremisme wordt als reëel beschouwd, aangezien extremisten, zoals de rechtse anti-islam partij Alternative für Deutschland (AfD), misbruik maken van de angst en zorgen van de burger. De toenemende instabiliteit van het (politieke) centrum en de polarisering van de samenleving worden in deze visie als veiligheidsrisico's gezien. Hiermee verbonden is de zorg dat het land radicaliseert en het politieke centrum naar rechts opschuift: 'Die Angst der Mittelschicht' (SZ, 22-1-2016, in: BK, 47). In meer of minder expliciete termen waarschuwen diverse berichten voor de symboolkracht van Keulen, omdat het een mogelijke verandering in de welkomstcultuur betekent: 'Seit den Übergriffen auf der Kölner Domplatte in der Silvesternacht bestimmen die Sorge vor den Fremden die öffentliche Diskussion' (FAZ, 17-1-2016, in: BK, 52). Keulen wordt hier gezien als katalysator die de reeds bestaande angst voor vreemdelingen vergroot en de vluchtelingenopvang ook voor de toekomst als veiligheidsprobleem definieert.

\section{Bezorgde burgers en leugenachtige pers}

Zoals reeds beschreven in de context van het veiligheidsframe, vindt in de berichtgeving over Keulen ook een discussie plaats over de mogelijke zorgen van de burger over migratie en het vluchtelingenbeleid. De angsten en zorgen van de

11 Een dergelijke eenzijdige toeschrijving van daderschap en slachtofferschap is ook in het \#MeToodebat te observeren. Seksualisering van de genderrelatie lijkt mij dan ook een kenmerk van dit debat. 
burgers zouden niet onderschat moeten worden en serieuzer moeten worden genomen, ook al zijn zij mogelijk irrationeel. De politiek moet hierop reageren en mag ze niet afdoen als rechts-populistische ressentimenten. 'Manche Sorge ist berechtigt, längst nicht alle sind Rechtspopulisten' (FAZ, 22-1-2016, in: BK, 48). In deze context krijgt niet alleen een terughoudende overheid kritiek, maar juist ook de media. Het verwijt 'Lügenpresse' wordt onderbouwd met de terughoudendheid van de pers, het achterhouden van de herkomst van de daders en het te laat berichten over de gebeurtenissen in de oudejaarsnacht. De FAZ en de SZ berichten er pas op 5 januari over en de beide weekbladen pas op 9 januari. De media krijgen, evenals de politie en de overheid, veel kritiek en het verwijt de gebeurtenissen in de doofpot te hebben willen stoppen. FOCUS spreekt in zijn eerste berichtgeving van misplaatse tolerantie: 'Frauen klagen an. Nach den Sex-Attacken von Migranten: Sind wir noch tolerant oder schon blind?' (FOCUS, 9-1-2016, in: BK, 25). ${ }^{12}$ De mediakritiek wordt niet exclusief, maar wel voornamelijk geuit door vertegenwoordigers van de Pegida-beweging en de sympathiserende partij AfD.

\section{Afronding}

Het mediale discours is duidelijk in zijn framing en presenteert de bedreiging van autochtone vrouwen door mannelijke vluchtelingen en de islam als interpretatiepatroon. De media-aandacht is gericht op deze twee geproblematiseerde en moreel beladen thema's: het vluchtelingenprobleem en aanrandingen. In de kern komen deze thema's op de meest simplificerende manier samen tot één beeld: het Duitse migratiebeleid met zijn welkomstcultuur heeft massaal allochtone jonge mannen als vluchtelingen toegelaten die de binnenlandse veiligheid en de (eigen) vrouwen bedreigen. Ongeacht het klaarblijkelijk falen van de politie om die nacht voor voldoende veiligheid te zorgen (Pütter, 2016: 48), wordt de herkomst van de vluchtelingen als het onveiligheidsprobleem geframed. Seksisme en seksueel geweld van autochtone mannen worden daarentegen nauwelijks geproblematiseerd. De daders van Keulen staan symbool voor alle mannelijke vluchtelingen en het genderdiscours wordt zo onderdeel van het discours over de islam. De sekse van de vluchtelingen is zo bezien een uitdaging voor of een provocatie van de genderrelaties.

De media-analyse laat ook zien dat Keulen een aanleiding is om het Europese migratiebeleid ter discussie te stellen en/of als gefaald te bestempelen. De angst voor vervreemding en verlies aan democratie gaat gepaard met de angst voor (rechts-)extremisme, terrorisme en geweld. De enorme publieke aandacht voor de oudejaarsnacht en de discussie over de oorzaken geeft aan dat met Keulen een verschuiving in het discours over vluchtelingen heeft plaatsgevonden. Vluchtelingen worden nu geassocieerd met seksueel geweld plegende allochtone jonge mannen.

12 Aan de andere kant is deze manier van berichtgeving in lijn met de journalistieke regel dat de afkomst van verdachten alleen bekend wordt gemaakt als dit nodig is om de berichtgeving te begrijpen (perscodex van de Duitse Raad voor de pers: www.presserat.de/pressekodex/ pressekodex\#panel-ziffer_12 diskriminierungen (geraadpleegd 1-3-2017)). 
De framing van de gebeurtenis in die nacht in Keulen schept een duidelijke orde wat de genderrelaties en hiermee verbonden de constructies van wij versus zij en de anderen betreft. Het zijn patriarchale denkbeelden waaraan wordt gerefereerd, die bepaalde voorstellen van mannelijkheid, de zogenoemde hegemoniale mannelijkheid inhoudt. Het idee van hegemoniale mannelijkheid veronderstelt dominante vormen van mannelijkheid en dat patriarchale structuren niet alleen de ongelijke relaties tussen mannen en vrouwen, maar ook specifieke groepen mannen en bepaalde voorstellen van mannelijkheid betreffen (cf. Carrigan, Connell \& Lee, 1985; Connell \& Messerschmidt, 2005). In het geval van Keulen zijn moslims en vluchtelingen diegenen die er als anders zijnde niet bij horen en 'hun' aanrandingen worden beschouwd als een aanval op de hegemoniale macht en genderrelaties.

\section{Maatschappelijke reacties}

In reactie op oud en nieuw in Keulen zijn veel protesten door maatschappelijke actoren ontstaan, waaronder verschillende feministische groeperingen en politici. Hierin wordt ook gesproken over het aanpassen van wetgeving en beleid.

\section{Feministisch protest}

\section{- $\quad$ EMMA \& Alice Schwarzer: 'Der Schock'}

Massaal protest in reactie op de gebeurtenis komt van EMMA. EMMA is sinds dertig jaar het politieke blad voor vrouwen in Duitsland en is gevestigd in Keulen. EMMA ziet zichzelf als Leitblatt des Feminismus. Oprichter, hoofdredacteur en uitgever van EMMA, Alice Schwarzer, geldt als de bekendste feministe van Duitsland. Op televisie is zij een veelgevraagde en populaire gast in bijvoorbeeld politieke talkshows, en in de dagen na oud en nieuw was zij hierin prominent aanwezig. Het perspectief van EMMA en de visie van Schwarzer zijn niet onomstreden, niet alleen in conservatieve kringen en media, maar ook in feministische netwerken.

Na oudejaarsnacht 2015 verschijnen al op 4 januari op de website van EMMA veelvuldig berichten van vrouwen over hun ervaringen in die nacht. 'Opfer melden sich bei EMMA. Und Frauen fragen: Wie konnte das geschehen, dass in der Silvesternacht mitten in Köln direkt am Hauptbahnhof Männer in großen Rudeln über Frauen herfallen' is het bericht onder de titel 'Frauen berichten EMMA vom Terror'. ${ }^{13}$ In mei 2016 publiceert Schwarzer het boek Der Schock - Die Silvesternacht von Köln, waarin zij beweert de tien uur op de Domplatte te willen reconstrueren en analyseren. De kern van dit boek vormt het door haar geschreven betoog 'Silvester 2015, Tahrir-Platz in Köln' ${ }^{14}$ Dit artikel staat symbool voor de 2017).

14 Het boek omvat daarnaast drie oudere artikelen van Schwarzer uit 2002, 2005 en 2010 en zeven artikelen van andere auteurs over de islam en de onderdrukking van vrouwen. 
berichtgeving in EMMA en vertegenwoordigt de politieke positie van EMMA als blad voor vrouwenrechten.

Schwarzer (2016: 35-39) vertelt over die nacht aan de hand van de verhalen van verschillende betrokkenen: een moeder met kleine kinderen, een Syrische vluchteling die een jonge Amerikaanse vrouw redt, een jonge vrouw die tijdens het spitsroeden lopen haar mannelijke partner kwijtraakt en de jonge man die haar niet kan helpen. Volgens Schwarzer is er die nacht sprake van een seksuele pogrom, van oorlogsspellen waarbij seksueel geweld het wapen is: 'die bricht die Frauen und demütigt die Männer, die "ihre" Frauen nicht schützen können. Und an diesem Abend demütigt sie auch Vater Staat' (Schwarzer, 2016: 16). Vrouwen zijn in deze schets dubbel slachtoffer van mannen. Opmerkelijk voor een politiek blad voor vrouwenemancipatie is hier wel de constructie van vrouwen die mannelijke bescherming nodig hebben en deze in die nacht kwijtraakten; een constructie die bij het idee van hegemoniale mannelijkheid aansluit.

Naast het slachtofferperspectief ligt de focus ook op de daders. Volgens Schwarzer (2016: 17-21) zijn ze: Noord-Afrikaan, Arabier, dus moslims, zich aan de letter houdende shariamoslims, fanatieke aanhangers van de sharia-islam en islamisten. Mannen voor wie vrouwen onrein zijn en die vinden dat deze 's nachts niet op straat horen te zijn, anders zijn ze Freiwild:

'Bei einem der Beschuldigten hat die Polizei einen Spickzettel gefunden mit deutsch/arabischen Sprüchen wie diesen: "Große Brüste" - "Ich will dich küssen" - "Ich töte sie ficken". Diese Männer hatten also nicht Feiern im Sinne, sondern Frauen-Klatschen. Ein Platz Tahrir mitten in Köln.' (Schwarzer, 2016: 19)

Volgens Schwarzer zijn alle verdachten van Keulen asielzoekers of illegalen en komt twee derde hiervan uit Marokko en Algerije. Deze 'fanatieke aanhangers van de sharia-islam en hun meelopers zijn de grootste groep vrouwenhaters ter wereld', beargumenteert Schwarzer (2016: 21) terwijl ze vele voorbeelden geeft. Zo wordt de burgermeester van Lampedusa aangehaald, die stelt dat alle vrouwen op hun vlucht worden verkracht door de mensensmokkelaars en door medevluchtelingen, ook in de boten. Schwarzer wordt ervan beticht racistische argumenten te gebruiken, maar wijst dit van de hand met een verwijzing naar 'Denkverbote'. EMMA werd al eerder van xenofobie beschuldigd door linkse feministen, maar, zo argumenteert Schwarzer:

'Mit diesem Versuch, die Fremdenliebe über die Frauenrechte zu stellen Anti Rassismus sticht Anti-Sexismus -, machen diese Selbstgerechten sich zu Komplizen der Täter. Denn sie verraten damit nicht nur ihre eigenen Frauen, sondern auch die Musliminnen: die auf der Flucht, die in den islamisch beherrschten Ländern und die hierzulande.' (ibid., 2016: 25)

Politieke correctheid is volgens Schwarzer de reden dat de herkomst van de daders van Keulen in het begin verzwegen werd. Valse tolerantie tegenover de islam en moslims is volgens Schwarzer de oorzaak van wat in Keulen is gebeurd. 
Schwarzer is daarbij niet terughoudend wat taal en generaliseringen betreft. ${ }^{15}$ Seksueel geweld is volgens haar niet alleen een probleem van islamitische landen, maar juist ook van Europese landen. Dat komt tot uitdrukking in de alledaagse terreur door jeugdbendes tot en met seksslavernij door IS. Hier worden de daders argumentatief op één lijn gesteld met de plegers van de terroristische aanslagen in Parijs en Brussel. Hoewel de 'shariamoslims' slechts een minderheid zijn, nuanceert Schwarzer, zijn ze wel gevaarlijk, omdat juist zij zich als woordvoerder opwerpen en ook zo beschouwd worden (ibid., 2016: 24-30).

\section{- \#Ausnahmslos}

De feministische kritiek van de beweging Ausnahmslos wijkt duidelijk af van de kritiek van EMMA. Onder de hashtag \#Ausnahmslos plaatst een groep feministen op 12 januari 2016 een oproep die breed verspreid wordt op social media. De oproep richt zich tegen elke vorm van seksuele grensoverschrijding en eist, zonder uitzondering ('ausnahmslos'), politieke prioriteit voor het dagelijkse gevecht tegen seksueel geweld. De oproep richt zich ook tegen elke vorm van discriminatie en racisme. Er is kritiek dat het onderwerp seksueel geweld alleen aan moslims wordt toegeschreven, terwijl er in Europa sprake is van een toename van seksueel geweld. Daarnaast luidt de kritiek dat de oudejaarsnacht in Keulen voor racistische en populistische doeleinden en retoriek wordt misbruikt.

'As feminists specialized on a variety of issues, we have been campaigning for gender equality, a fair and open society, and against sexism and sexualized violence for many years. We have learned how important it is to stand firmly against racism and other forms of discrimination.' (Against sexualized violence and racism. Always. Anywhere. \# ausnahmslos ('noexcuses').)

www.ausnahmslos.org/english

Volgens de website is de oproep binnen één week door elfduizend mensen ondertekend, mede door honderden politici. Een lijst met politieke oplossingen wordt gesteund door nationale en internationale ondertekenaars. Deze lijst omvat een negenpuntenplan: versterking van consultatiebureaus voor vrouwen en blijf-vanmijn-lijfhuizen; aanpassing van de wetgeving omtrent aanranding en intimidatie; uitbreiding van voorlichtings- en bewustwordingscampagnes; meer aandacht voor preventie door gendersensitieve pedagogiek; training van politie en justitie om het probleem te erkennen en er professioneel mee om te kunnen gaan; een open en kritisch debat over seksueel geweld; serieuze erkenning van de slachtoffers van seksueel geweld en geen victim blaming; seksisme en racisme niet als problemen aan de ander toeschrijven; seksisme en seksueel geweld niet tolereren, maar ingrijpen, ook als omstander.

De oproep is daarnaast speciaal gericht aan de media. In vijf punten wordt meer bewustwording van seksisme geëist: mediaberichtgeving mag slachtoffers niet belachelijk maken, daders verontschuldigen of hen als 'Seks-Mob' aanmerken. 
Seksueel geweld heeft niets met seks te maken, zo wordt geredeneerd. Seksisme en andere vormen van discriminatie moeten worden gezien als voedingsbodem voor seksueel geweld. Mediaal seksisme is rechtstreeks verbonden met seksueel geweld. Seksisme en seksueel geweld mogen niet worden geïslamiseerd of afgeschilderd als een probleem van bepaalde etnische afkomst. Mediabeelden moeten vrij zijn van seksistische en racistische stereotypen. De personeelssamenstelling van mediaredacties moet diverser worden.

De twee stemmen van het feministisch protest over Keulen verschillen enorm in hun interpretatie van het gebeuren in die nacht en leveren zeer verschillende verklaringen en probleemoplossingen. Volgens EMMA maakt vrouwenonderdrukking deel uit van de islam en de moslimcultuur. Hier wordt islamofobisch geargumenteerd en met verwijzing naar de gelijkheid van mannen en vrouwen vrouwenonderdrukking geculturaliseerd. Dit is kenmerkend voor het (zogenoemde) neoliberale feminisme. Gelijkheid en vrijheid zijn hier gekoppeld aan het idee van de superioriteit van westerse waarden en ideeën, waarin specifieke voorstellen over vrijheid en zelfbeschikking domineren. Zoals duidelijk wordt in de framing van EMMA construeert een dergelijk perspectief niet alleen essentialistische genderstereotypen over mannen en vrouwen, maar tegelijkertijd hiermee verbonden racistische voorstellen. Het (intersectionale) idee van sociale gelijkheid dat niet alleen de onderdrukking van vrouwen, maar verschillende elkaar kruisende ongelijkheden betreft, krijgt hier geen erkenning. Vrouwen worden hier als homogene groep beschouwd wat hun onderdrukkingservaringen betreft, daderschap en slachtofferschap zijn eenzijdig gegendered. Seksueel geweld wordt beschouwd als van buiten komend en de ongelijke behandeling van de anderen, de vluchtelingen, wordt hiermee verbonden en als gelegitimeerd en gerechtvaardigd beschouwd.

Kenmerkend voor het feminisme van \#ausnahmslos is een gelijkheidsdenken met solidariteit en politiek engagement juist niet alleen voor de eigen groep. Hun standpunt komt overeen met ideeën van het radicale feminisme die het misbruiken van sociale gelijkheid door stereotypering en discriminatie bekritiseren, zoals de seksualisering van vluchtelingen in het debat over Keulen. Seksisme of racisme is kenmerkend voor een ongelijke maatschappij en resultaat van structurele machtsongelijkheden. Gelijkheid van mannen en vrouwen betreft hier de ongelijke behandeling in een gelijke situatie. Anders gezegd, gaat het radicale feminisme over bevrijding van vrouwenonderdrukking in de context van de (machts)gelijkheid van alle vrouwen én van alle mensen, de gelijkheid tussen diverse categorieën mensen. Het intersectionale perspectief komt hier duidelijk tot uitdrukking; de veronderstelling is dat ongelijkheid niet alleen door gendercategorieën ontstaat, maar doorkruist wordt door verschillende andere vormen van ongelijkheid, achterstelling en discriminatie zoals sekse, afkomst, nationaliteit, geloof en leeftijd. Er is dus veel meer sprake van een wisselwerking van verschillende ervaringen van discriminatie en van multiple identiteiten (Althoff, 2013).

\section{Politieke reacties en wetswijzigingen}

Het Duitse zedenstrafrecht staat al langer ter discussie, maar na de nacht van Keulen ontketent zich een heftig debat, onder andere gevoerd door verschillende 
vrouwennetwerken en ngo's, dat uiteindelijk tot een wetswijziging leidt. Als kernprobleem wordt gezien dat aanranding onvoldoende strafrechtelijk geregeld is. Afhankelijk van de manier waarop de aanranding plaatsvindt, wordt deze strafrechtelijk al dan niet vervolgd. De reden hiervoor is de zogenoemde 'Erheblichkeitsschwelle'. De aanranding moet 'aanmerkelijk' zijn om strafrechtelijk te worden vervolgd. Dit geldt bijvoorbeeld niet voor aanranding boven de kleding (Lemke, 2016: 1). Ook moet het delict verbonden zijn met het plegen van extra geweld. Critici stellen dat met deze wetgeving aanranding in de publieke ruimte nauwelijks kan worden vervolgd, omdat deze gekenmerkt is door snelheid en het verrassende effect, wat juist extra geweld overbodig maakt (Lemke, 2016: 3f). ${ }^{16}$ Half maart 2016 maakt de regering bekend dat het Duitse zedenstrafrecht wordt aangescherpt. Op 7 juli 2016 debatteert de Bondsdag over een aanzienlijke hervorming van het zedenstrafrecht en neemt deze met unanimiteit van stemmen aan. Op 10 november 2016 is de nieuwe wetgeving van kracht. Het nieuwe strafrecht richt zich tegen elke seksuele handeling tegen de herkenbare wil van een persoon, ongeacht of deze persoon weerstand biedt. Opgenomen in het nieuwe strafrecht is ook seksuele intimidatie, een delict dat eerder als niet erheblich werd beoordeeld. Nieuw is ook de opname van delicten waarbij gebruik wordt gemaakt van het verrassingseffect, een duidelijke link met de gebeurtenissen in Keulen. De nieuwe wet blijft niet zonder kritiek. Kritische strafrechtjuristen spreken bijvoorbeeld van symboolpolitiek en bekritiseren deze wijziging als een reactie op de oudejaarsnacht. ${ }^{17}$

De meest opvallende veranderingen in de wetgeving na de oudejaarsnacht vinden plaats in de vreemdelingenwet. ${ }^{18}$ De nieuwe versie van het Duitse verblijfsrecht was net op 1 januari 2016 van kracht geworden. Na de oudejaarsnacht van Keulen gaat de regering rechtstreeks de discussie aan over een hernieuwde versie. Al op 16 februari 2016 wordt over een wetsvoorstel gedebatteerd dat de uitwijzing van buitenlanders met een strafdossier vergemakkelijkt en de gronden waarop asielzoekers kunnen worden uitgesloten van een vluchtelingenstatus verruimt. ${ }^{19} \mathrm{De}$ wetswijziging wordt zonder grote aanpassingen, een maand later, op 11 maart 2016 aangenomen. De redenen voor uitzetting zijn in het nieuwe verblijfsrecht verwoord als onderdelen van strafbare feiten die, indien begaan, tot een officiële uitwijzing leiden. Een veroordeling tot een gevangenisstraf van minimaal een jaar

16 Het verwijt aan het Duitse strafrecht is niet nieuw. $\mathrm{Al}$ in 2014 had de Istanbul Convention (Council of Europe Convention on preventing and combating violence against women and domestic violence) de vraag opgeworpen of het Duitse zedenstrafrecht aan de eisen voldoet.

17 Zie bijvoorbeeld Monika Frommel, Jenseits von Patriarchat und Islam, 28-01-2016, www.novoargumente.com/artikel/koeln_jenseits_von_patriarchat_und_islam (geraadpleegd 01.03.2017). Zie ook Walburg, 2016: 284.

18 Een rechtstreeks effect van de oudejaarsnacht is dat er maatregelen zijn genomen om immigrerende alleenstaande mannen uit de Maghreblanden sneller uit te wijzen naar hun land van herkomst (Behrendes, 2016: 323). Het wetsvoorstel om de Maghreblanden als veilige herkomstlanden te definiëren wordt echter op 10 maart 2017 door de Bondsraad afgewezen.

19 Entwurf eines Gesetzes zur erleichterten Ausweisung von straffälligen Ausländern und zum erweiterten Ausschluss der Flüchtlingsanerkennung bei straffälligen Asylbewerbern, http:// dip21.bundestag.de/dip21/btd/18/075/1807537.pdf (geraadpleegd 3-3-2017). 
(of onvoorwaardelijke jeugddetentie) wordt als zwaarwegende reden voor uitwijzing beschouwd (Lederer, 2016: 59f.).

In de nasleep van Keulen heeft in het politiek-parlementaire debat de constructie dat aanranding een dreiging is die in eerste instantie van vluchtelingen uitgaat zich hardnekkig gemanifesteerd. Samen met de discussie over de aanpassing van het zedenstrafrecht heeft dit in 2016 tot een tweede aanpassing van het verblijfsrecht geleid. Deze aanpassing volgt het voorstel dat juist ook een voorwaardelijke veroordeling voor aanranding en intimidatie (volgens het nieuwe zedenstrafrecht) als reden tot uitwijzing moet worden opgenomen in het verblijfsrecht. De wijzigingen in de vreemdelingenwet krijgen het verwijt symboolpolitiek te zijn (cf. Lederer, 2016; Walburg, 2016). Het uitzetten van criminele vluchtelingen en asielzoekers, zo luidt de argumentatie, was ook vóór Keulen, onder het oude verblijfsrecht mogelijk. De verbinding van migratie met strafrecht wordt hier duidelijk en werd eerder omschreven als crimmigratie (Stumpf, 2006; Walburg, 2016). Criminaliteitsbestrijding vindt in toenemende mate plaats door uitwijzing: strafrecht is hierbij een eenvoudig beschikbaar hulpmiddel. Juist het hierop aansluitende uitzettingsrecht is van hoge symboolkracht, omdat het criminaliteitsbestrijding en beheersing van migratie laat zien. Tegelijkertijd wordt migratie als veiligheidsprobleem geframed, waarbij de dreiging uitgaat van de mannelijke vluchteling.

\section{Securitisering en seksualisering van het vluchtelingendebat}

De securitisering van migratie framet de relatie tussen vluchtelingen en veiligheid als veiligheidsprobleem. Het feit dat er in het migratiedebat over het vluchtelingenprobleem, het vluchtelingendrama en de vluchtelingencrisis wordt gesproken, in plaats van bijvoorbeeld over de crisis van het Europees migratiebeleid (Widersprüche, 2016: 4), is hier een voorbeeld van. Het discours over oud en nieuw in Keulen heeft aan deze securitisering een dimensie toegevoegd door de seksualisering van het vluchtelingenprobleem. Of anders gezegd, de problematisering van migratie vanuit een veiligheidsperspectief vindt plaats via het thema seksualiteit en seksuele relatie.

\section{Het veiligheidsdiscours: 'carnaval van angst'}

De massaliteit van de overtredingen en aanrandingen tijdens oud en nieuw bevestigen het frame van vluchtelingen als veiligheidsprobleem. Het beeld van de meer dan duizend slachtoffers vinden we maanden later nog in de mediaberichten terug. Er blijken meer dan duizend aangiftes te zijn gedaan; tegelijkertijd is er sprake van duizend aanwezigen. Het lijkt erop dat iedere aanwezige dader of slachtoffer was. Het genoemde aantal verdachten is hoog, maar er kan van worden uitgegaan dat de dark number klein is. Het aangiftegedrag is gestimuleerd door de herhaaldelijke oproepen van de politie, het OM en de overheid, maar ook door de massale publieke aandacht voor die nacht. Een vraag die zich vanuit criminologisch perspectief opdringt, is of het hoge aantal aangiftes ook uitdrukking 
geeft aan de onderschatting en/of niet-rapportage van seksuele intimidatie en seksueel geweld op vergelijkbare publieke evenementen (zoals carnaval of het Oktoberfeest) waar normaliter weinig aangiftes worden gedaan. Empirische gegevens hierover zijn er niet. Wel zijn er aanwijzingen ${ }^{20}$ hiervoor en is er de verklaring dat enerzijds stigmatisering en anderzijds bagatellisering van seksueel geweld het doen van aangifte tegenwerkt. Volgens Römkens (2015) is het bekend dat collectieve seksuele vergrijpen tegen vrouwen in het openbaar vaker voorkomen en geen uitzondering zijn in Europa, ook al hebben deze tot nu toe minder aandacht in de media gekregen. Als voorbeeld noemt zij de aanranding van serveersters op het Oktoberfeest in Alkmaar in 2015 en de regelmatige groepsaanrandingen van vrouwen in Spanje tijdens het San Ferminfestival. Net als de speciale rapporteur van de VN voor geweld tegen vrouwen noemt Römkens geweld tegen vrouwen een probleem van epidemische proporties (ibid., 2015: 570). ${ }^{21}$

Daarnaast moet ervan uit worden gegaan dat er sprake is van overregistratie. In de drukte van een massaal event kan snel elke stoot als aanranding worden geïnterpreteerd, met name als nadrukkelijk om melding wordt gevraagd en de morele verontrusting over de totale gebeurtenis groot is. Het kwijtraken van een mobieltje kan het resultaat van diefstal zijn, maar ook van de drukte. Na oud en nieuw had het doen van aangifte zeker ook een symbolische waarde en was dit uitdrukking geworden van moreel protest. Dit wordt door het eindrapport van de officiele onderzoekscommissie bevestigd. Hier komt nog bij dat de maatschappelijke problematisering van seksualiteit typisch blijkt voor onze tijd. Volgens de criminologen Lautmann en Klimke (2016: 5) was het erotische veld nog nooit eerder zo hevig omringd met gevarendiscoursen: discoursen waarin seksueel misbruik en pedofilie als de meest dringende problemen worden beschouwd. Publieke discoursen ontplooien zich rondom de topos van het seksueel slachtoffer en poneren deze als centraal maatschappelijk probleem. ${ }^{22}$

20 Kort geleden werd bijvoorbeeld in Zweden het idee geopperd om festivals te organiseren waar alleen vrouwen worden toegelaten (zie https://nos.nl/artikel/2181609-mannenvrij-festival-inzweden-totdat-ze-zich-allemaal-gedragen.html). Zie ook het blog van Barbara van Dam, 'Veiligheid van vrouwen op evenementen', www.eventsafetyinstitute.nl/nieuws/veiligheid-vrouwen-opevenementen.

21 Cijfers hierover zijn wel beschikbaar, maar hebben veel methodologische beperkingen, omdat ze het resultaat zijn van grootschalige en internationaal vergelijkende enquêtes, die o.a. met een brede geweldsdefinitie werken om internationaal vergelijkbaar te zijn. Volgens onderzoek van de European Agency for Fundamental Rights rapporteert één op de negen vrouwen seksueel geweld door een partner. $45 \%$ van alle vrouwen in Nederland wordt in haar leven ten minste één keer slachtoffer van seksueel of lichamelijk geweld vanaf de leeftijd van vijftien, http://fra.europa.eu/ en/publications-and-resources/data-and-maps/survey-data-explorer-violence-against-womensurvey (geraadpleegd 27-08-2017).

22 Een voorbeeld hiervan is ook \#MeToo dat zich met de casus van Hollywood Harvey Weinstein tot een hype heeft ontwikkeld en zich focust op mannen die hun hoge sociale positie en macht in de beroepscontext misbruiken voor seksuele 'aanrandingen' van vrouwen. Opvallend in het zich uitbreidende debat is de individualisering, verontschuldiging, maar ook ontkenning en bagatellisering door de betrokken mannen. Volgens mij is hier dan ook eerder sprake van seksualisering van de genderrelaties dan van het problematiseren van de ongelijke machtsrelaties. Zie ook voetnoot 11. 
Onveiligheid is het dominante frame in het discours over Keulen, waarbij de dreiging van vreemde moslimmannen uitgaat. De unanieme beeldvorming over die nacht en de verantwoordelijke daders is stereotyperend en polariserend. De polarisering zit in de dader-slachtofferdichotomie: de daders - mannelijke vluchtelingen, kleurlingen, islamitisch, gevaarlijk en potentieel gewelddadig, seksueel hyperactief en niet vertrouwd met de westerse cultuur van respect voor recht, eigendom en vrouwen - staan tegenover de slachtoffers - vrouwen, jong, blank en blond, christelijk, modern en geëmancipeerd: 'That representation replaced the real subjects with "masks" and presented their acts as an expression of the "clash of civilization"' (Melotti, 2016: 136). De daders worden niet geïndividualiseerd (als mensen met een individuele persoonlijkheid en verantwoordelijkheid), maar op basis van hun herkomst gekarakteriseerd, gehomogeniseerd en als sociale groep neergezet: 'typified and reconfigured as masks of fear' (ibid., 2016: 137). De constructies zijn racistisch, omdat het verschijnsel geseksualiseerd geweld uitsluitend aan vreemdelingen, de ander, wordt toegeschreven.

\section{The field of sayable: etnisering van seksisme}

Het discours over de oudejaarsnacht maakt Keulen tot symbool voor een maatschappelijke crisis die gekenmerkt wordt door maatschappelijke verontwaardiging verbonden met normatieve onzekerheden. De slachtofferverhalen, de berichten van getuigen, de massaliteit van de aangiftes, maar ook de politieke consequenties voor beleid en wetgeving zijn eenduidig in hun definitie van het probleem: de (seksuele) dreiging en het seksisme uitgaande van de vluchtelingen en hun genderbeeld. Hier wordt het anders-zijn, the otherness, vast omschreven en symbolisch gecontrasteerd met de normen en waarden en de cultuur van het 'gastland'. De argumentatie is xenofoob, omdat het seksisme 'geëtniseerd' wordt: othering through gendering. Volgens een recent onderzoek naar Europees rechtspopulisme en xenofobie is othering van seksueel geweld een wijdverbreid patroon:

'Gendered nationalism and xenophobia build a common ideological ground of right-wing actors ... The most important discursive construction is the (young) foreign criminal and violent perpetrator. [...] The need for safety is gendered and ethnicized' (Mayer, Sori \& Sauer, 2016: 94).

De analyse van het debat over Keulen maakt duidelijk dat dit niet alleen een betekenispatroon van rechtse actoren en discoursen is, maar dat met het discours over Keulen dat wat mag worden gezegd over vreemdelingen - the field of sayable - is verruimd: 'What can be said and be accepted in a discourse, seems to have been enlargened' (Braun-Klöpppel, 2016: 53). Seksisme wordt in het discours gekoppeld aan de islam en seksisme geëtniseerd, oftewel toegeschreven aan de etnische herkomst van de vluchtelingen. Hiermee is wel sprake van een oud patroon in het migratiediscours: de Oriënt als de ander. Seksueel geweld en seksisme zijn een probleem van de anderen en komt (altijd) van buiten. Het effect is het creëren van culturele superioriteit, maar ook van homogenisering van de westerse cultuur en homogenisering van vreemdelingen. Het verwijst naar de nietgelijkgerechtigde genderrelaties in de islam tegenover die van de westerse cultuur: 
geëmancipeerd, liberaal en niet-seksistisch. Seksisme en seksueel geweld vormen de bagage van vreemdelingen en zijn een importprobleem; de probleemoplossing is dan ook uitsluiting of uitwijzing. Hierbij wordt wel een paradox zichtbaar: het 'eigen' seksisme en de 'eigen' maatschappelijke tekortkomingen in de genderrelaties zijn niet bespreekbaar en worden onzichtbaar gemaakt (Dietze, 2016: 97). Seksueel geweld wordt in het discours bijna uitsluitend in de migratiecontext geproblematiseerd. Er zijn weinig stemmen die hier expliciet tegenin gaan, zoals de kritische feministen van \#ausnahmslos of de internazionale. ${ }^{23} \mathrm{Zij}$ verwijten de deelnemers aan het debat populistisch instrumentalisme. De weerstand om het alledaags (autochtoon) seksisme te benoemen is een centraal element van dit risicodiscours. Het lijkt volgens Dietze (2016: 98) alsof de autochtone, blanke, heteroseksuele mannen in dergelijke (onveilige) tijden niet gedestabiliseerd mogen worden door seksismekritiek.

'There is no Islamic monopoly on violence and the subordination of woman. And nor is there any Western or democratic monopoly on women's freedom. [...] unfortunately, men's violence against women is one of the few examples of universal behavior still known to the world.' (Bocchetti, Dominijanni, Pomeranzi \& Sarasini, 2016)

\section{Symboolpolitiek in onveilige tijden}

Securitisering is een kenmerk van de westerse samenlevingen, waarin veiligheid zich heeft ontwikkeld tot een grootschalig programma voor sociale orde: 'Het strafrecht werd in normatieve zin richtinggevend in de preventie van criminaliteit, antisociaal gedrag en serieuze bedreigingen. Het vormt niet langer de begrenzing van de samenleving, maar de wegwijzer in de morele ruimte' (Boutellier, 2013: 181). De vervlechting van de strafrechtshandhaving met allerlei geproblematiseerde maatschappelijke verschijnselen is dan ook een consequentie hiervan. De vervlechting van het strafrecht met het vreemdelingen- en migratierecht (ook 'crimmigratie' genoemd, cf. Stumpf, 2006) is hiervan een voorbeeld, evenals de hierboven beschreven maatschappelijke tendens van een toenemend geseksualiseerd risicodiscours. Het idee dat het strafrecht een oplossing biedt voor deze veiligheidsproblemen is een valkuil, maar het strafrecht heeft wel enorme symboolkracht. Anders dan dat kunnen de versnelde aanpassingen van het zedenstrafrecht in Duitsland of de aanpassing van het verblijfsrecht en zijn koppeling met het strafrecht niet worden geïnterpreteerd. Van symbolisch karakter is ook het al eerder geïntroduceerde concept dat culturele lessen over gendergelijkheid verplicht worden gesteld als onderdeel van het integratietraject. Een voorbeeld waarover in Nederland recentelijk is gesproken is het verplicht ondertekenen van een of Cologne' is een internationaal opiniestuk geschreven door vier Italiaanse feministes dat op 3 februari 2016 op internet verscheen. 
zogenoemde participatieverklaring als onderdeel van de inburgering. ${ }^{24}$ Het afdwingen van de ondertekening van een dergelijke verklaring, is eenvoudig te realiseren maar evenzo een symbolische oplossing. Uit (straf)rechtssociologisch perspectief is dit bovendien een onzinnig idee om normen en waarden af te dwingen. De veronderstelling erachter is dat normen en waarden statische regels zijn die indien geleerd ook getolereerd en onafhankelijk van de context toegepast worden.

\section{Conclusie}

Oud en nieuw in Keulen - wat was hier eigenlijk aan de hand? Welke betekenis heeft die nacht in Keulen gekregen en wat kunnen we concluderen over de geanalyseerde culturele framingen?

Een eerste belangrijke conclusie is dat het publieke debat over oud en nieuw in Keulen zich heeft ontwikkeld tot een discussie over het thema migratie en de zogenoemde vluchtelingencrisis. Tijdens het begin van het publieke debat over de politie-inzet domineert het verwijt dat de politie informatie zou hebben achtergehouden ten faveure van het migratiebeleid. De reconstructie van die nacht laat echter zien dat de politie in die nacht weinig controle over de gebeurtenissen had. Deskundigen spreken in meer of mindere mate over het falen van de politie. Pas met de publicatie van het slotrapport van het parlementaire onderzoek is het falen van de politie een erkend frame. De problematisering van het vluchtelingenbeleid domineert hiertegenover het hele debat. Vluchtelingscrisis, een mislukt vluchtelingenbeleid, integratieproblemen en meer algemeen het thema migratie worden hier aangehaald, dienen als framing van die nacht en worden verbonden met het veiligheidsperspectief. In aansluiting op Goffman is hiermee duidelijk wat het probleem, de hiermee verbonden oorzaken en de oplossingen zijn en staat Keulen symbool voor een veiligheidsprobleem veroorzaakt door migratie.

Een tweede conclusie is dat seksueel geweld geëtniseerd wordt en als cultureel probleem is weggezet. Het problematiseren van seksueel geweld in de publieke ruimte is een dominant frame, maar door uitsluitend vluchtelingen hiervoor verantwoordelijk te maken en als daders aan te wijzen, wordt uiteindelijk de brug gebouwd naar het problematiseren van het thema migratie. Deze specifieke en eenzijdige problematisering van het thema seksueel geweld tegen vrouwen impliceert een bagatellisering van aanrandingen in het algemeen. Bagatellisering wordt

24 Alle nieuwkomers (asielmigranten en migranten die komen in het kader van gezinsvorming en -hereniging) moeten dit traject doorlopen bij de gemeente. Het doel hiervan is migranten 'al in een vroeg stadium na hun vestiging in Nederland kennis te laten maken met de Nederlandse normen en waarden', www.rijksoverheid.nl/actueel/nieuws/2016/04/29/internetconsultatieparticipatieverklaring. Een inleiding in de Nederlandse kernwaarden en de ondertekening van de participatieverklaring maken deel uit van het traject. Met de ondertekening verklaart de nieuwkomer kennis te hebben van de waarden en spelregels van de Nederlandse samenleving en deze te respecteren. Het conceptwetsvoorstel is in april 2016 ingediend. Op 23 februari 2017 stemt een ruime meerderheid van de Tweede Kamer in met deze aanpassing van de Wet inburgering, www.rijksoverheid.nl/documenten/formulieren/2016/08/23/participatieverklaring-2016. 
mogelijk door geweld tegen vrouwen als cultureel probleem neer te zetten dat enkel speelt onder sociale groepen van niet-westerse herkomst. Deze culturalisering van seksueel geweld ontkent dimensies van macht en sociale ongelijkheid als kenmerken van seksueel geweld en de intersectionale dimensie van sociale ongelijkheid. ${ }^{25}$ Ze maakt racisme onzichtbaar door de solidariteit met de slachtoffers, aangewezen als 'onze' vrouwen. De etnisering van seksueel geweld en het polariseren van seksueel geweld dat wel daar, maar niet hier gebeurt, voedt de angst voor vervreemding, omdat deze unaniem aan de vluchtelingen en hun culturele ideeën over genderrelaties toegeschreven wordt.

In het publieke debat zijn ook pogingen te zien tot een andere framing van het incident in Keulen waarin de machtsongelijkheden tussen mannen en vrouwen in zijn algemeenheid worden geproblematiseerd. Het zijn kritische tegenstemmen die echter maar beperkt erkenning krijgen, mogelijk omdat ze nieuwe onzekerheden over de bestaande genderrelaties creëren en sociale (on)gelijkheid en macht in plaats van seksualiteit en geweld problematiseren. In tijden die gekenmerkt zijn door fluïde identiteiten en (ontologische) onzekerheden (Bauman, 2000; Beck, 1986) biedt het vasthouden aan of teruggrijpen op vaste (gender)identiteiten zekerheid en oriëntatie en schept het ordening in de sociale verhoudingen. Dit verklaart ook het teruggrijpen op geïnstitutionaliseerde betekenissen over de genderrelaties of over de westerse en niet-westerse cultuur. De framing van het publieke debat kent (bestaande) negatieve classificaties toe en bepaalt wie erbij hoort en wie niet.

Keulen staat nu symbool voor een mislukt migratiebeleid. De discursieve betekenis van die nacht in Keulen maakt nu deel uit van het collectieve geheugen, sluit aan op oude betekenissen over de anderen én stelt nieuwe collectieve en culturele betekenissen beschikbaar (primary framework), waarop in de toekomst en in de volgende publieke debatten teruggegrepen kan worden. Zo is er een maatschappelijke scheidslijn ontstaan tussen vóór en na Keulen.

\section{Literatuur}

Althoff, M. (2010), Mediaberichtgeving en het maatschappelijke discours over criminaliteit en geweld in de publieke ruimte. In: M. Althoff \& J. Nijboer (red.), Zoeklicht op geweld. Sociale conflicten in het publieke domein. Den Haag: Boom Juridische uitgevers, 201-218.

Althoff, M. (2013), Multiple identities and crime: A study of Antillean women and girls in the Netherlands. European Journal of Criminology, 10(4), 394-407.

Bauman, Z. (2000), Liquid Modernity. Cambridge: Polity Press.

Beck, U. (1986), Risikogesellschaft. Auf dem Weg in eine andere Moderne. Frankfurt a.M.: Suhrkamp.

25 De culturalisering van seksueel geweld gaat volgens Römkens (2015: 571, 572) gepaard met een genderneutralisering van geweld en 'heeft dan niets meer van doen met ongelijkheid en lijkt daar helemaal los van te staan', hoewel 'problematisch seksueel gedrag en dito normen (...) niet uniek noch specifiek voor moslims' zijn. 
Behrendes, U. (2016), Die Kölner Silvesternacht 2015/2016 und ihre Folgen. Neue Kriminalpolitik, 28(3), 322-343.

Bocchetti, A., I. Dominijanni, B. Pomeranzi \& B. Sarasini (2016), Speculum, the Other Man. Eight Points on the Spectres of Cologne. www.internazionale.it/opinione/bocchettidominijanni-pomeranzi-sarasini/2016/02/03/speculum-other-man-spectres-cologne.

Boutellier, H. (2013), De securitisering voorbij? Een beschouwing over de toekomstige ontwikkeling van het Nederlandse veiligheidsbeleid. Tijdschrift over Cultuur \& Criminaliteit, (3)2, 173-184.

Braun-Klöppel, A. (2016), The Refugee Discourse in German Media. An analysis of the changes provoked by the events of New Year's Eve 2015 in Cologne. Master of Arts Thesis Euroculture. University of Göttingen (Home) \& University of Uppsala (Host).

Carrigan, T., R.W. Connell \& J. Lee (1985), Towards a new sociology of masculinity. Theory and Society, 14(5), 551-604.

Connell, R.W. \& J. Messerschmidt (2005), Hegemonic masculinity. Rethinking the concept. Gender \& Society, 19(6), 829-859.

Dietze, G. (2016), Das 'Ereignis Köln'. FEMINA POLITICA, 1, 93-102.

Goffman, E. (1974), Frame Analysis: An Essay on the Organization of Experience. Boston: Northeastern University Press.

Lautmann, R. \& D. Klimke (2016), Zur Produktivität des Strafrechts im sexuellen Feld. In: D. Klimke \& R. Lautmann (red.), Sexualität und Strafe. 11. Beiheft Kriminologisches Journal. Weinheim: Beltz, 5-16.

Lederer, A. (2016), Ausweisungsrecht reloaded. Bürgerrechte \& Polizei/CILIP 111, Oktober 2016, 57-65.

Lemke, U. (2016), Sexuelle Übergriffe im öffentlichen Raum - Rechtslage und Reformbedarf in Deutschland. www.legal-gender-studies.de/sexuelle-uebergriffe-imoeffentlichen-Raum-rechtslage-und-reformbedarf.

Mayer, S., I. Sori \& B. Sauer (2016), Gendering 'the people'. Heteronormativity and 'ethnosmasochism' in populist imaginery. In: M. Ranieri (red.), Populism, Media and Education. Routledge, 84-104.

Melotti, M. (2016), The carnival of fears: The 2016 violence in Cologne. In: B.M. Pirani \& T. Spence Smith (red.), Embodiment and cultural differences. Cambridge Scholars Publishing, 132-146.

Prins, B. (2000), Voorbij de onschuld. Het debat over de multiculturele samenleving. Amsterdam: Van Gennep.

PUA (2016), Parlamentarischer Untersuchungsausschuss 'Silvesternacht 2015'. Landtag Nordrhein-Westfalen, 16. Wahlperiode, Drucksache 16/10798, www.landtag.nrw.de/ portal/WWW/GB_I/I.1/PUA/PUA_IV_16._WP/MMD16-10798_Einsetzungsantrag. pdf.

PUA (2017), Schlussbericht des Parlamentarischen Untersuchungsausschusses IV. Landtag Nordrhein-Westfalen,. 16. Wahlperiode, Drucksache 16/14450, www.landtag.nrw.de/ portal/WWW/dokumentenarchiv/Dokument/MMD16-14450.pdf.

Pütter, N. (2016), Polizeiversagen: Kölner Silvesternacht. Bürgerrechte \& Polizei/CILIP 111, Oktober 2016, 47-56.

Römkens, R. (2015), De Keulse kwestie: over de culturalisering van geweld en genderongelijkheid. Sociologie, 11(3/4), 565-575.

Schneider, F. (2016), Die Kölner Silvesternacht. Rekonstruktion eines diskursiven Ereignisses. DISS-Journal, 31. www.diss-duisburg.de/2016/07/die-koelner-silvesternacht.

Schorer, J. \& F. Schneider (2017), Die Silvesternacht 2015 in Köln. Eine Ereignisanalyse. In: M. Jäger \& R. Wamper (red.), Von der Willkommenskultur zur Notstandsstimmung. Der Fluchtdiskurs in deutschen Medien. Duisburg: DISS, 147-180. 
Schütz, A. (1971), Über die mannigfaltigen Wirklichkeiten. In: A. Schütz, Gesammelte Aufsätze I. Das Problem der sozialen Wirklichkeit. Den Haag: Martinus Nijhoff, 237-298.

Schwarzer, A. (2016), Der Schock - Die Silvesternacht von Köln. Köln: Kiepenheuer \& Witsch.

Stumpf, J. (2006), The crimmigration crisis: Immigrants, crime \& sovereign power. American University Law Review, (56), 376-419.

Walburg, Ch. (2016), 'Crimmigration': Die Ausweisung als Mittel der Migrations- und Kriminalitätskontrolle. Neue Kriminalpolitik, 28(4), 378-388.

Widersprüche Redaktion (2016), Flucht - Provokationen und Regulationen. Zu diesem Heft. Widersprüche, (36) 141, 3-10. 